SOME MANGANESE MINES IN VIRGINIA AND MARYLAND.

\author{
By D. F. HewetT.
}

\title{
INTRODUCTION.
}

The demand for large amounts of manganese ore arose with the development of the modern steel industry as a result of the introduction of the Bessemer and open-hearth processes of making steel during the period 1865 to 1870 . To satisfy this demand the deposits of the territory easily accessible from the iron and steel producing centers of the Eastern States were actively exploited. Thus most of the deposits of Virginia, Georgia, and Arkansas that are now known were discovered and explored between 1875 and 1895. Domestic deposits have, however, failed to supply the increasing demands of the steel industry, and although in 1890 the domestic production of manganese ores was almost equal to the imports, for the five-year period. 1910 to 1914 it was but 1 per cent of the imports.

Owing to the fact that Virginia appears to possess a larger number of deposits than adjacent States and to her proximity to markets, Virginia has supplied a large part of the domestic production. This part has ranged from about one-fifth during years of depression to nearly the whole, and the average proportion for the period 1880 to 1914 was 61 per cent. Nearly two-thirds of this ore is said to have come from one mine, the Crimora, in Augusta County.

The present paper is based on data collected during brief visits in the spring months of 1913,1914 , and 1915 , in connection with the gathering of statistics of the production of manganese ore. Four of the mines described in this paper, with the Crimora, Evington, and a few others, have produced practically all the manganese ore mined in Virginia for the last five years. The location of the mines is shown in figure 4. From two of the mines here described, the Kendall \& Flick and the Piedmont, ore has been mined more than 200 feet below the surface, which was about the greatest depth that had been attained in manganese mining in Virginia. The visits to the Niesswaner shaft of the Kendall \& Flick mine were opportune, for deep work was soon afterward stopped and the shaft is now abandoned. With the exception of the Crimora deposit, which is much larger, the deep zone of the deposit at this mine has probably been more thoroughly explored than any other in Virginia. 
One object in presenting this paper, in addition to describing the occurrence of the ores, is to call attention to the presence of four types of deposits, one of which has not been previously recognized

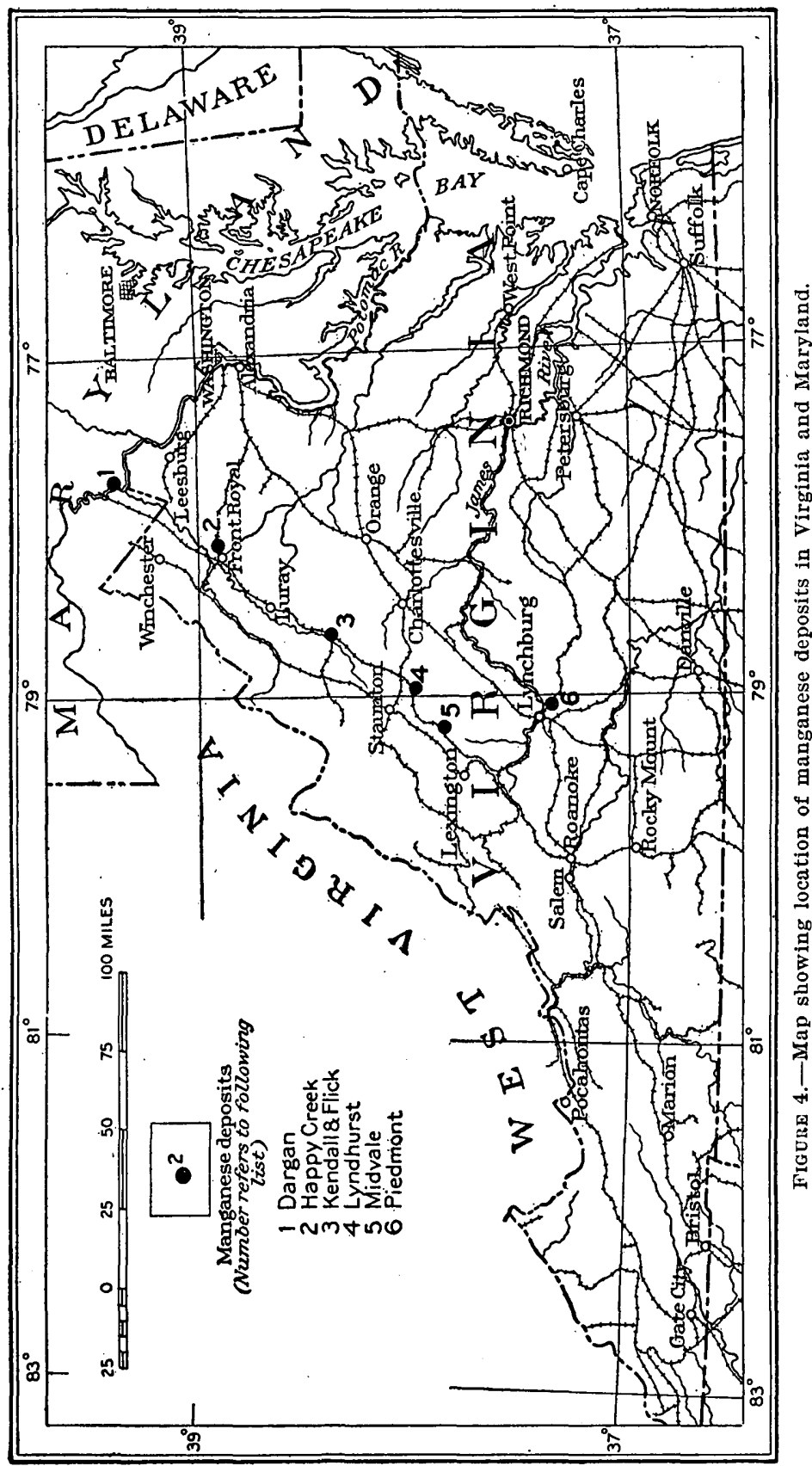

in Virginia. These four types of deposits offer essentially the same problems in exploitation, but the chances of persistence of the manganese minerals in depth appear to be different for each type. Atten- 
tion is drawn also to a possible relation of the deposits to the erosional features of the region.

The exploitation of manganese mines in Virginia appears to have been profitable only rarely when viewed over the entire period of exploration. Doubtless many factors have contributed to this result. If further investigation should tend to support the hypothesis that is here set forth, it may serve as an aid in the search for new deposits as well as the exploration of those already known.

\section{MINERALS OF THE ORES.}

The manganese minerals in the ores of this region are few in number, and belong to the group of brown to black oxides and hydrous oxides, several of which can not be positively identified without analysis. In the following description the usage of names and the identification of species are based on the table prepared by Fermor ${ }^{1}$ as the result of considerable study in connection with the preparation of the report on the manganese deposits of India. $\mathrm{He}$ says:

In naming Indian specimens of manganese ores the practice $I$ have followed with regard to the uncrystallized or amorphous ores is to designate all those as psilomelane that in any way exhibit the characters of that mineral, the hardness especially being a criterion. If the mineral be a soft one and show a finely crystalline structure, I have relegated it to pyrolusite, whilst if it shows no signs of crystalline structure nor of the compact, firm, amorphous structure of psilomelane, I have called it wad, this term being thus reserved for the indefinite mixtures so often found in manganese-ore deposits.

Psilomelane is the commonest manganese mineral in the Virginia deposits and forms more than 75 per cent of the washed ore. Its distinguishing features are its rounded or botryoidal forms, its lack of crystalline outlines, and its hardness-it can not be scratched by a steel knife. The composition is complex, and although the percentage of manganese ranges only from. 50 to 57 , the amounts of minor accessory ingredients, such as iron, barium, and potassium, show a wide range. The percentage of water ranges from 2.5 to 6.0.

Manganite, a hydrous oxide containing 62.4 per cent of manganese and 10.3 per cent of water, is present in most of the ores, but in many specimens it is not conspicuous. It is distinguished by its crystal forms, which are commonly needle-like, bladed, or wedgeshaped, and its degree of hardness, as it is softer than a knife blade. Compared with psilomelane, it is of simple composition, for the accessory ingredients of psilomelane are absent.

Wad includes a number of poorly defined hydrous minerals that contain a large proportion of manganese oxide and minor amounts of such accessory substances as barium oxide, iron oxide, and clay.

1 Fermor, L. L., The manganese-ore deposits of India : Geol. Survey India Mem., vol. 37, pt. 1, pp. 117, 228-229, 1909. 
It is commonly a loosely coherent brown powder not sharply defined from the clay in which it usually occurs. It contains from 30 to 42 per cent of manganese and 7 to 10 per cent of water.

Pyrolusite, which is now regarded as formed from manganite by the loss of most of the water, a change that causes a loss of coherence, has not been definitely recognized in any of the ores. Dark steelgray powder forms irregular masses in clay at several mines, notably at Happy Creek, but tests of a number of specimens in a closed tube consistently show more water than pyrolusite. The materials are grouped with wad.

The data gathered in connection with this investigation show that the relations of the manganese minerals bear some resemblance to those noted by Fermor ${ }^{1}$ in deposits of the Sandur Hills and Mysore, in India, in which wad is commonly present. Noting the persistent occurrence of psilomelane in masses of wad, Fermor states:

It is evident from the mode of association of these two minerals that the wad is the first-formed mineral and that it subsequently gets converted into psilomelane, probably on the advent of a further portion of manganese in solution.

Although there are here and there, as at the Piedmont mine, large masses of wad free from nodules of psilomelane, and elsewhere, as at Happy Creek, nodules of psilomelane in lenticular zones of clay with no wad, in most of the deposits the nodules of psilomelane occur in masses in wad that more or less completely replace the residual clay. It appears that psilomelane, which contains less water than wad, tends to form most readily in masses of wad. Many nodules that appear to be wholly psilomelane, however, show in a polished section alternating thin layers of psilomelane and manganite. In some nodules manganite fills sharply defined veinlets in psilomelane and is clearly later in origin. From this it appears that there is no uniform trend from the formation of the more hydrous to the less hydrous oxides of manganese. Although the chemical reactions of the process are obscure, the method of formation of nodules of manganese ore appears to be similar to that by which concretions of silica, calcium carbonate, and barium sulphate are formed.

The amorphous clays that occur in the manganese deposits show a great range in color. Locally these clays contain a large proportion of limonite, and every transitional stage to wad may be. observed. Nodules of limonite, some of which are highly siliceous, are common in the surface zone at Happy Creek and have been found sporadically at Midvale and in the Niesswaner shaft, at Elkton, but limonite is generally rare on the lower levels. Sericite is sporadically present, but much of the clay adjacent to the masses of ore is free 
from it. In addition to angular grains of quartz that are residual from the rocks in which the deposits occur, quartz occurs in several varieties that appear to have been formed during the decomposition of the bedrock. The commonest of these is a microcrystalline variety which generally occurs as thin veinlets in clay but which here and there, as in the Niesswaner shaft, forms rounded nodules as large as 2 inches in diameter. Quartz also occurs at Elkton and Happy Creek as minute doubly terminated needle-shaped crystals with numerous rounded nuclei of calcite.

\section{NATURE OF THE DEPOSITS.}

Except for a few descriptions of isolated mines, such as that of the Crimora mine by Hall, ${ }^{1}$ the most important contributions to the knowledge of the manganese deposits of Virginia have been based upon systematic examinations of practically all the mines in operation in the State at any one time. As a result of his investigations in 1889 Penrose $^{2}$ reached the conclusion that the ores of the Blue Ridge region as mined represented the weathered and decomposed outcrops of persistent beds of sediments of Cambrian age which were not only much richer in manganese than the adjacent sediments but that the manganese ores occurred in the beds in essentially the same condition as they are found in the superficial mine workings. $\mathrm{He}$ though that the inclosing masses of clays were derived from the decomposition of the adjacent sediments. A consequence of this view would be that the ores should be traceable over the surface in persistent belts coincident with the outcrop of the manganiferous beds and should persist downward as far as the beds continue.

As the result of an extensive investigation covering the entire United States in 1908 Harder, ${ }^{3}$ while recognizing that in Virginia, Tennessee, and Georgia a belt of manganese deposits coincides roughly with the outcrops of a group of Cambrian shales and quartzites, concluded that the presence of the deposits is determined by an impervious stratum of underlying quartzite, but that the manganese has probably been derived from manganiferous minerals disseminated. through a thick group of beds of shale and limestone. He alsa concluded that the ores as mined were formed both by replacement of residual clays and by deposition in pervious channels, such as breccia and fault zones. According to this view, manganese oxide minerals would not persist deeper than the zone accessible to circulating waters of surface origin.

1 Hall, C. E., Geological notes on the manganese ore deposits of Crimora, Va. : Am. Inst. Min. Eng. Trans., vol. 20, p. 46, 1892.

2 Penrose, R. A. F., Manganese, its uses, ores and deposits : Arkansas Geol. Survey Ann. Rept. for 1890 , vol. 1, p. $385,1891$.

3 Harder, E. C., Manganese deposits of the United States: U. S. Geol. Survey Bull. 427, p. 99, 1910.

$37757^{\circ}-$ Bull. $640-17-4$ 
The following description recognizes four types of replacement deposits-(1) in residual clay, (2) in the clay of a fault zone, (3) along pervious zones in schistose rocks, and (4) in channel sediments. Each of these types except the last was recognized by Harder.

1. Replacement masses in residual clay are well shown in the deposit near Elkton, Va., explored through the Niesswaner shaft. In this deposit manganese minerals occur in nodules that are largely if not wholly confined to masses of manganiferous clay and wad formed by the replacement of residual clay in beds of shale. The masses of wad occur sporadically in a $U$-shaped zone roughly parallel to the limits of the partly decomposed underlying shale, which is relatively free from manganese. The composition of the clay is not known, but it is probably ferruginous kaolin formed in part by the decomposition of sericite. The deposit has been explored to a depth of 312 feet, but the deepest ore came from a depth of 260 feet, or 220 feet below the original water level.

2. Replacement masses in clay along a fault zone are well shown in the deposit near Dargan, Md., on the north side of Potomac River. In the narrow vertical zone of this deposit that was explored manganese oxides in the form of nodules and soft powder replace clay derived from the decomposition of shale breccia along an extensive thrust fault. The shale, which is composed of quartz, mica, and amorphous materials, is not so completely decomposed as the residual clay at Elkton, Va. Manganese ore has been mined at a depth of about 40 feet below water level. The Happy Creek deposit may belong to this type, but the clays resemble those at Elkton.

3. Replacement masses along pervious zones in schistose rocks are represented by the lenses of ore of the Piedmont mine, east of Lynchburg, Va., where relatively pure masses of manganese oxides replace quartz-mica schist along sharply defined nearly vertical zones. Some clay and wad are associated with the ore, but the mica of the replaced schist is fresh. The lens has been explored to a depth of 208 feet, or 170 feet below water level, and shows a maximum length of 125 feet and width of 30 feet. The adjacent wall rocks are undecomposed.

4. Replacement masses in channel sediment are illustrated by the deposit at Midvale, Va. This type of deposit, though noted by Penrose, ${ }^{1}$ near Columbia, Tuolumne County, Cal., apparently has never been exploited commercially heretofore. At Midvale masses of manganese ore partly replace the clay which, with associated sand and gravel, fills a channel cut in limestone of Lower Cambrian age (Shady limestone). One border of the channel has been explored 
to a depth of 150 feet, but manganese ore appears to be confined to the higher levels. On the 50 -foot level ore has been mined sporadically over an area about 100 feet square. As the original source of the clay is not known, the amount of alteration that has taken place can not be inferred. The sand and gravel have the properties of common river sediment.

\section{RELATIONS OF THE DEPOSITS TO THE SURFACE.}

All'but one of the six deposits that are referred to in this paper are situated on the east side of the valley that lies west of the Blue Ridge and is commonly known as the Great.Valley of Virginia. The other deposit lies well east of the Blue Ridge, in the Piedmont region. As most observers now agree that the manganese ores of the Great Valley and Piedmont regions have been deposited from solutions that derived their metal content from the weathering and erosion of the rocks in the neighborhood, the deposits may be examined in the light of their relation to the erosional history of the region.

The conditions that led to the development of the prominent surface features of Virginia and similar parts of the neighboring States have been the subject of considerable study. The most valuable contribution to the knowledge of these surface features is that of Hayes and Campbell, ${ }^{1}$ who consider that those long stretches of the Blue Ridge in Virginia, which now rise to uniform elevations of about 2,300 feet, represent parts of an extensive erosion surface or peneplain which has been elevated and dissected. The few isolated peaks that rise considerably higher are regarded as having stood as mountains above this old erosion surface in consequence of their resistance to the processes of erosion. The peneplain is believed to have been established during late Jurassic and Cretaceous time and to have been elevated and warped during late Cretaceous time. It is known in northern Virginia and Pennsylvania as the Kittatinny peneplain. There appears to be no record of manganese deposits on the mountains that project above it.

In the west half of Virginia, especially east of the Blue Ridge, there are extensive areas of flat upland below which the larger streams have cut their valleys as much as 400 feet. Above this upland, which ranges in altitude from about 850 feet above sea level near Lynchburg to 1,400 feet near Staunton, project the long stretches of the Blue Ridge. This peneplain has been traced by residual areas over the region from central Alabama to eastern Pennsylvania. It is cut in the softer rocks, such as limestone and

\footnotetext{
${ }^{1}$ Hayes, C. W., and Campbell, M. R., Geomorphology of the southern Appalachians : Nat. Geog. Mag., vol. 6, pp. 63-126, 1894.
} 
shale, and the ridges that project above it are composed of more resistant rocks, such as quartzite and siliceous metamorphic rocks. As the altitudes of the residual areas vary from place to place, it is concluded that this upland, like the higher peneplain, has been elevated and broadly warped in a somewhat similar manner. This upland, known as the Harrisburg peneplain, was formed during early Tertiary time and uplifted by several successive movements during late Tertiary time. After the first of these movements a third and still lower plain, known in Pennsylvania and New Jersey as the Somerville peneplain, was locally developed. This plain has been recognized in the Shenandoah Valley at Harpers Ferry, at about 530 feet above sea level, or 120 feet below the Harrisburg plain, but it is not easily distinguished from the Harrisburg plain at the south end of the Shenandoah Valley.

The relation of the outcropping part of each of the deposits described in this report to these erosion surfaces is quite clear. The highest point of the explorations of the Dargen deposit, near Potomac River, is about 350 feet below the early Tertiary peneplain, but a tunnel in the same fault zone 4,000 feet farther north, at the elevation of the Somerville peneplain, encountered a small quantity of manganese ore. In comparison with the relations of the other deposits, the fault along which this deposit lies should offer an exceptional opportunity for the circulation of underground water. The explorations of the Lyndhurst and Piedmont mines start about 50 feet below the average elevation of the early Tertiary peneplain, but the Midvale, Happy Creek, and lower Kendall \& Flick deposits crop out approximately at the elevation of this peneplain. The higher Kendall \& Flick deposit crops out nearly 150 feet higher than the peneplain, and the deposit worked in the Crimora mine, which was visited but not examined in detail, crops out where the peneplain merges with adjacent ridges east of Shenandoah Valley.

With regard to the relation of the outcrops to the local surface features, the Piedmont, Midvale, Happy Creek, and Dargan deposits are situated near the top or along the slopes of isolated hills or spurs, so that since dissection of the peneplain began they have received very little of the surface drainage or ground water that might contain manganese in solution. The Lyndhurst and Crimora deposits lie along stream channels sunk below the surrounding plain and therefore may have received accessions of manganese in solution. The fact that the deep levels of the Piedmont and Midvale deposits yield only a little water tends to show that the water they contain is now relatively stagnant. If, as there is good reason to believe, the manganese that now forms the masses of ore was brought to its present position in solution in ground water of local origin, the four deposits first named must have been formed during some 
stage of early Tertiary erosion, when the surface features permitted the local drainage to reach the areas in which they lie.

It is possible that manganese deposits like those here described, as well as similar masses representing concentrations of other substances, such as iron oxide, might be formed either by regular but small accessions of material over a long period, such as that extending from early Tertiary time to the present, or by relatively rapid accumulation over a shorter period, or by both processes. It is thought that the relations of four of the deposits to the surface features preclude the first possibility, although, of course, manganese oxide may have been dissolved and reprecipitated to a slight extent within each deposit up to the present time. It is concluded, therefore, that the masses of the manganese oxide that now make up the deposits represent the rapid accumulation during a period geologically brief.

In determining more accurately the period during which accumulation of manganese oxide took place, the probable nature of erosion as shown by the relation of rock decay and solution to rock disintegration and removal in the region since the Cretaceous or Kittatinny peneplain was established must be considered.

The most favorable conditions for the formation of a manganese deposit probably exist when, through rock decay, large quantities of manganese oxide in solution are permitted to migrate along a zone that offers favorable conditions for deposition. With the uplift of the Kittatinny peneplain the gradients of streams and consequently their capacity for carrying sediment increased, and rock waste was removed as rapidly as it was formed. It seems probable that until the streams had cut their channels nearly to base-level, or the level represented by the early Tertiary peneplain, rock decay and solution were slight compared with rock disintegration and removal, although on account of the greater relief of the surface then than at any subsequent time oxygen-bearing waters were permitted to penetrate most deeply. It is also probable that during the period when the valleys were being broadened disintegration and removal were more effective than decay and solution, although not so much more as previously. The depth to which surface waters were permitted to circulate was probably as great during this period as before. From this period to that in which the peneplain was established over extensive areas of soft and soluble rock, rock decay and solution became more active than rock disintegration and removal, but on account of the low relief of the surface the zone accessible to surface waters was not so deep as previously, though it extended below the level of the streams.

During the period when peneplanation was being perfected locally there was probably little rock disintegration and removal, but solution and decay were going on in the zone accessible to migrating 
waters that contained oxygen. At this time the best conditions for the solution of large amounts of manganese probably existed, but as the relief of the surface was low the opportunity for circulation in localized channels was poor. During the next stage in the erosional history of the region, that represented by the uplift of the early Tertiary peneplain, the gradients of the streams and consequently their capacity for transporting sediment were again augmented, but also with the increase in surface relief the opportunity was afforded for more active circulation of water to deeper levels.

In considering the effectiveness of the processes that went on during the last two periods in aiding the accumulation of manganese oxide it is necessary to balance the duration of the first period against the better facility for circulation during the second period. There is no doubt that the depth below the peneplain to which the ores are known to occur is a good reason for placing a considerable part of the accumulation in the last period, but it is also known that surface water may descend much deeper below the surface than the difference in elevation between the points of entrance and outlet, ${ }^{1}$ a difference which on the early Tertiary peneplain was probably in some places as much as 100 feet. The data are not available at present to evaluate properly the relative importance of these two periods in the formation of the masses of manganese ore.

It may be noted that in examining that part of the Piedmont region in North and South Carolina in which gold deposits occur Graton ${ }^{2}$ concluded that the thick cover of residual soil was formed during the later stages of peneplanation, before uplift had taken place.

There is good reason for regarding the sediments that contain the Midvale deposit as a remnant of an early Tertiary river-channel deposit. The similar material overlying the Happy Creek deposit and near the Elkton deposits may be either terrace or channel gravels.

It would be unwise without further study to assert that all the manganese deposits of Virginia or the region from Alabama to eastern Pennsylvania were formed during the early Tertiary period of erosion, but it is interesting to note that this suggestion was once made for the Appalachian deposits of iron ore, which have a similar areal distribution, as a result of the discovery of small basins of lignite of Tertiary age near Brandon, Vt., ${ }^{3}$ and Pond Bank, Pa., ${ }^{4}$

1 Van Hise, C. R., Some principles concerning the deposition of ores : Am. Inst. Min. Eng. Trans., vol. 30 , pp. 55-56, 1900.

${ }^{2}$ Graton, L. C., Gold and tin deposits of the southern Appalachians: U. S. Geol. Survey Bull. 293, p. 13, 1906.

3 Hitchcock, Edward, Description of a brown coal deposit at Brandon, Vt., with an attempt to determine the geological age of the principal ore beds of the United States: Am. Jour. Sci., ser. 2, vol. 15, p. 95, 1861.

- Lesley, J. P., Lignite in iron ore at Pond Bank, Franklin County, Pa.: Am. Phllos. Soc. Proc., vol. 9 , pp. $463-482,1864$. 
near deposits of iron ore. It was then thought, however, that the residual iron ores within this entire region were the weathered residue of an essentially continuous horizontal iron-bearing bed. This assumption is not necessary, but it is reasonable to suppose that conditions during early Tertiary time may have favored, more than those of later periods, the solution and transportation of iron and manganese salts to favorable sites for deposition. The existence of many extensive deposits of residual iron ore and related laterite in regions having warm and moist if not tropical climates has long been recognized. In this connection it may be noted that Berry, ${ }^{1}$ as a result of the study of the floras of the Upp?r Cretaceous and Eocene formations of the Coastal Plain of South Carolina and Georgia, concludes that the prevailing climate of that region at the time these beds were laid down was mild and humid, with possibly a brief period during Eocene time that was less mild.

Spencer ${ }^{2}$ has noted that the large deposits of brown hematite of Mayari, in the Province of Oriente, Cuba, underlie an extensive rolling plain that is regarded as a remnant of a peneplain, possibly of late Tertiary age. Eckel ${ }^{3}$ states that most of the brown hematite ores of the Birmingham district were formed during Tertiary time.

\section{PERSISTENCE OF THE ORES.}

As they have considerable bearing on the successful exploitation of other deposits of manganese ores in Virginia, the data that have been gathered in the examination of these mines may be summarized. In the Niesswaner shaft, at Elkton, sporadic masses of ore were found 260 feet below the surface, although the richest zone was 50 feet or more higher. The deposit clearly replaces residual clay forming a pocket in shale. It is reported that ore was mined at a depth of 256 feet in the old Kendall \& Flick shaft, but the nature of this deposit is not known. The lens of ore of the Piedmont mine was not appreciably smaller at the lowest level, 208 feet deep, than on the higher levels. According to Watson ${ }^{4}$ the greatest depth at which ore was found at Crimora is 198 feet, or 14 feet above the quartzite which underlies the deposit.

In some respects the origin of these manganese deposits resembles that of the iron ores of the Mesabi Range, Minn., ${ }^{5}$ where extensive

1 Berry, E. W., The Upper Cretaceous and Eocene floras of South Carolina and Georgia : U. S. Geol. Survey Prof. Paper 84, pp. 122, 158, 1914.

a Spencer, A. C., Three deposits of iron ore in Cuba: U. S. Geol. Survey Bull. 340, p. 318, 1908.

s Eckel, E. C., Iron ores, fuels, and fluxes of the Birmingham district, Ala.: U. S. Geol. Survey Bull. 400, p. 149, 1910.

4 Watson, T. L., Mineral resources of Virginia, p. 249 : Jamestown Exposition Commission, 1907.

${ }^{5}$ Leith, C. K., The Mesabi Iron-bearing district of Minnesota : U. S. Geol. Survey Mon. 43, 1903. Van Hise, C. R., and Leith, C. K., The geology of the Lake Superior region: U. B. Geol. Surrey Mon. 52, 1911. 
masses of soft hematite have been formed by the oxidation of the iron and solution of the silica contained in beds of "greenalite," a mineral composed essentially of ferrous oxide, silica, and water." In the Mesabi district the ground-water level is about 75 feet below the surface, ${ }^{2}$ and, although ores are locally found at a depth of 500 feet, most of the deposits lie within 300 feet of the surface. ${ }^{3}$

The conclusion may be tentatively drawn that in the VirginiaMaryland region aluminous minerals can be decomposed to amorphous clays to a depth of nearly 300 feet from the surface and 250 feet below water level, and that manganese ores may be formed in such clays from 250 to 300 feet below the surface. From analogy with similar deposits it is very doubtful whether manganese ores in any of these deposits will persist 500 feet below the surface, and a more probable limit is 400 feet. If all the manganese deposits of this region were largely formed during the early Tertiary erosion cycle, the lowest levels of the Dargan mine, 410 feet, represent the deepest explorations below the plain. The fault along which this deposit lies has probably offered exceptional opportunity for the 'deep circulation of underground water.

The different structural relations of the ores shown to exist among the mines described and the range in persistence of the different types of deposits emphasize the necessity for exhaustive areal study of the region near the deposits of such ores, in addition to the mine examinations ordinarily made.

\section{PREPARATION OF THE ORES.}

The machinery and methods used in the preparation of manganese ores for the market closely follow those used for the brown or limonite iron ores that occur throughout the region in which the manganese ores are found. Modern practice includes three operations-first, the treatment of crude ore in a log washer to free the nodules of manganese ore from the plastic clay in which they are embedded; second, the sizing of the coarse ore in trommels, where the smallest particles, generally those less than one-eighth inch in diameter, are rejected; third, the jigging of the separate sizes in order to eliminate the siliceous minerals from manganese minerals. Recently, in order to obtain the higher prices brought by finely ground ore, some companies have equipped their mills with drying and pulverizing machinery.

The modern log washer differs little from its early predecessor, except that the use of a steel frame permits the use of longer machines. It consists essentially of a central shaft 20 to 30 feet long,

${ }^{1}$ Leith, C. K., op. cit., p. 245.

2 Idem, p. 235.

${ }^{3}$ Van Hise, C. R., and Leith, C. K., op. cit., p. 186. 
made either of a wooden beam or of structural steel, around which a series of logs or paddles are bolted so as to form a spiral. This shaft rotates with its axis inclined slightly from the horizontal and is suspended in a trough, so that when ore is added near the lower end it is slowly pushed up the trough and out of the higher end. A stream of water enters the higher end and carries away in suspension from the lower end the clay and fine particles mixed with the ore. Double washers contain two parallel shafts that rotate in opposite directions and give a greater output and a cleaner product.

Many mills are equipped simply with washers and attempt to recover only the coarse lumps of ore. Lumps that contain more silica than the limit permitted by makers of alloys must be crushed and further cleaned in jigs. For this purpose a jig of the common Harz type is used, but recently this has been superseded by jigs permitting closer control of the plunger action. Several mills have attempted to treat the sizes smaller than one-eighth inch on tables, but none appear to have made a marketable product successfully.

\section{THE MINES.}

\section{PIEDMONT MINE.}

\section{LOCATION AND HISTORY.}

The Piedmont mine, also known as the Lerner or Myers mine, is situated on a low knob adjacent to Beaver Creek, 2 miles south of James, Campbell County, Va., on the Norfolk \& Western and Chesapeake \& Ohio railways. James is 6. miles east of Lynchburg. (See fig. 4, p. 38.) It is reported that many years ago iron ore was drawn from pits in the neighborhood, several of which are situated between the two shafts marked 1 and 2 on figure 5, and the walls of an old stone furnace with piles of slag may be seen 3,000 feet north of the mine. Manganese ore was first mined here in the early nineties by the Lerner Mining Co. from pits near the Josephine shaft. From 1902 to 1912, under the ownership of the Piedmont Manganese Co., ore was drawn from the Josephine shaft to a depth of 105 feet, but the most vigorous development took place from 1912 to 1914 . During this period the lessee, the Piedmont Manganese Corporation of New York, built a narrow-gage tramway from the mill to the Chesapeake \& Ohio Railway, extracted ore to a depth of 150 feet from the Josephine shaft, and sank the new Oxford shaft 190 feet deep. The Oxford Mining \& Manganese Co. sank the Oxford shaft to 208 feet in 1915 and mined ore to that level. The present owner is sinking the same shaft with the intention of mining the deeper ores. It is reported that the total yield

${ }^{1}$ Harder, E. C., op. cit., pp. 38-40. This mine should not be confused with the Piedmont mine in Nelson County. 
from the Josephine shaft between the 105 and 190 foot levels was 5,052 tons, and the total production from all workings on the hill about 30,000 tons of washed ore.

\section{SURFACE FEATURES AND GEOLOGY.}

The Piedmont region in this part of Virginia is a relatively flat upland having an altitude of 750 to 850 feet above sea level, but a

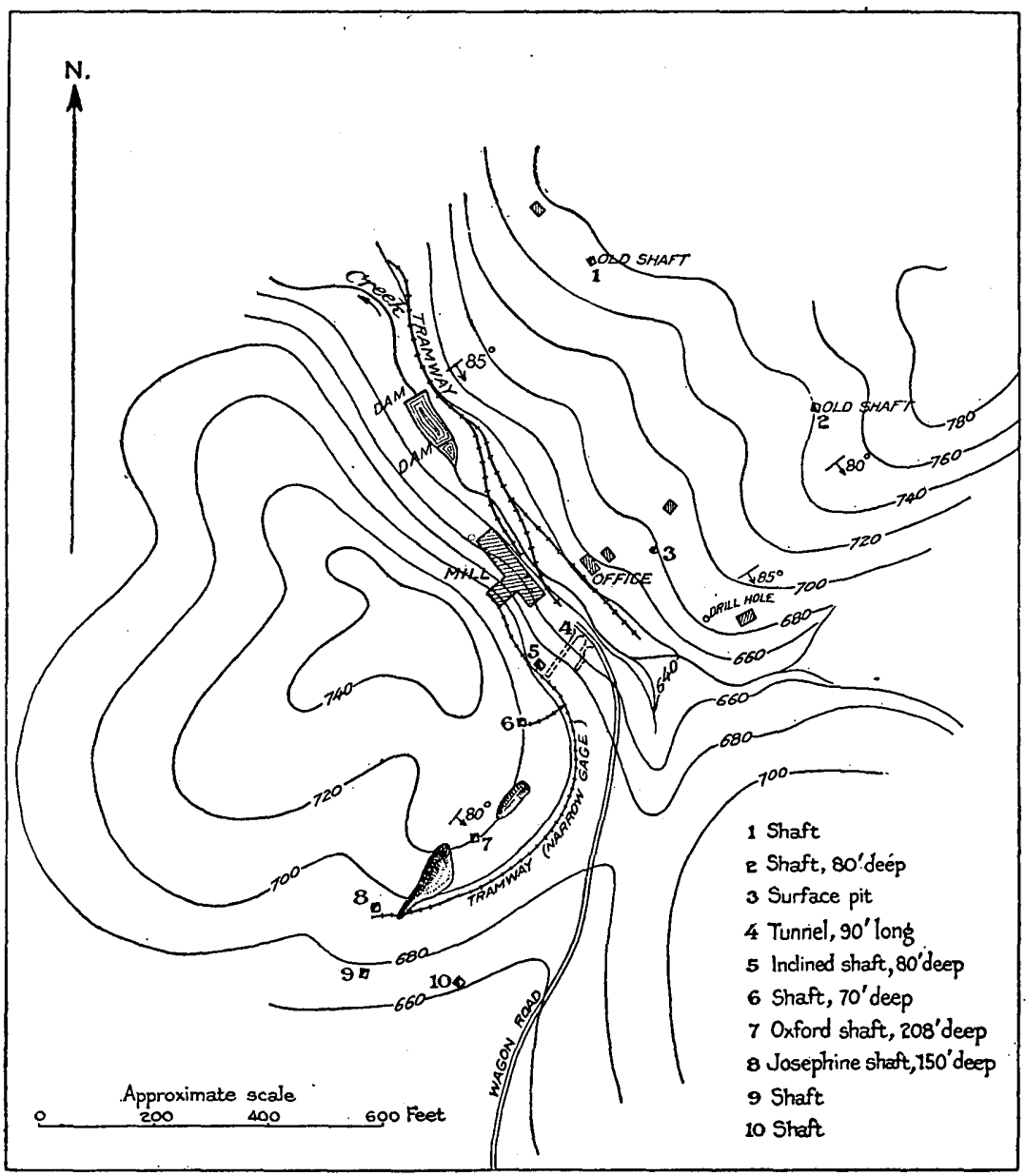

Figure 5.-Sketch map showing location of the workings of the Piedmont mine, Campbell County, Va.

few isolated hills and ridges rise to altitudes ranging from 1,100 to 1,400 feet. The principal stream, James River, flows in a narrow valley cut nearly 300 feet below the level of this upland, the normal stage of the river at James being 480 feet above sea level. The minor streams, such as Beaver Creek, also flow in narrow valleys cut 100 to 150 feet below the level of the upland. Where Beaver Creek meets James River there are small remnants of a terrace on 
both sides of the river at an altitude of about 625 feet. As the upland probably represents the early Tertiary peneplain, these remnants may indicate a minor late Tertiary cessation in the downcutting of the valley, and are possibly equivalent to the Somerville peneplain of Pennsylvania and New Jersey.

The manganese deposits that have been most thoroughly explored lie on the south slope of a low knob that rises to an altitude of 750 feet, or about 100 feet above Beaver Creek, which almost encircles the knob. Ore has been mined from the 208-foot level of the Oxford shaft, 130 feet below the level of Beaver Creek and 170 feet below the original water level.

The rocks in the vicinity of the mine embrace a wide range of schistose types in which the planes of bedding and schistosity appear to coincide. Observations of strike range from N. $35^{\circ} \mathrm{E}$. to N. $60^{\circ}$ E. and of dip from $75^{\circ} \mathrm{SE}$. to $80^{\circ} \mathrm{NW}$. Beginning on the southeast, there are successive belts of gray to light-green muscovite schist with here and there clusters of magnetite grains and crystals of almandite garnet; a reef 50 to 75 feet wide of gray quartz-muscovite schist with numerous quartz lenses; and finally white crystalline limestone, locally with considerable dark-green chlorite mica, which forms the southeast wall of the manganese deposit. Northwest of the deposit greenish muscovite schist predominates, but there are also bands for fine-grained quartzite. Both pyrite and pyrrhotite are common in the schists and limestone. Between the mill and James River outcrops commonly show thin veins of pegmatite and quartz that lie parallel to the schistosity.

According to Watson ${ }^{1}$ these rocks form part of a belt which extends the entire length of the Piedmont region in Virginia and which has been shown to contain sediments of Cambrian age. ${ }^{2}$

\section{OCCURRENCE OF THE ORE.}

Manganese minerals occur in many pits and trenches in the neighborhood of the Piedmont mine, but the larger masses appear to be confined to two belts that follow the schistosity of the rocks. The northern belt, which lies beyond the limits of the area shown in figure 5 , has been prospected at three points over a distance of about 2,500 feet, but hard nodules of manganese ore have been found only at the northeasternmost point, where a 40 -foot shaft was sunk some years.ago. In this belt thin lenses of soft black manganese oxide alternate with bands of quartz-mica schist, forming zones that are locally as much as $\mathbf{1 0}$ feet wide but of unknown linear extent. In such zones manganese oxide appears to replace an unknown ingredi-

\footnotetext{
1 Watson, T. L., Geological map of Virginia, Charlottesville, 1910.

2 Watson, T. L., and Powell, S. L., Fossil evidence of the age of Virginia pledmont slates : Am. Jour. Sci., 4 th ser., vol. 31, p. 36, 1911.
} 
ent in the schist, leaving the mica and much of the quartz unattacked. In one tunnel bands of soft manganese oxide contain coarse angular fragments of quartz, with relations which suggest that manganese oxide replaces the clay of a fault breccia, but this type of occurrence is unusual. The presence in this belt of hard nodules of manganese minerals in quantities that will be profitable to work has not yet been demonstrated.

In addition to sporadic pockets northeast of the mill, the southern belt contains two considerable masses of ore. The more southwestern and larger has been mined through the Josephine and Oxford shafts, and the other through shafts marked 5 and 6 on figure 5. These two masses are separated by an area of unaltered barren mica schist. Masses of soft manganese-bearing clay and wad were found in the tunnels at the point marked 4, but these tunnels have not yet disclosed much hard ore. The writer's observations of the larger deposit were confined to a part of the 208foot level of the Oxford shaft, the Josephine shaft having been abandoned in 1913. The map showing the extent of the workings from these two shafts (fig. 6) is based on surveys by the company. The explorations from these shafts to a depth of 208 feet and for a horizontal distance of 175 feet show that manganese ore and clay formed a well-defined lens that pitched steeply to the southwest along the planes of schistosity. The maximum width on successively lower levels has ranged from 22 to 30 feet, and according to the maps of the several levels ore has been mined for a distance of 125 feet and explored a short distance farther. All the material from the lens was mined, and the yield of washed ore ranged from one-third to two-thirds of the weight of mine dirt. The average yield is considerably higher than any other on record from mines west of the Blue Ridge.

Harder, ${ }^{1}$ who saw the mine in operation at the 80 -foot level in 1909, gives the following description of the occurrence of the ore:

The ore occurs in kidneys or large masses and is mainly in the form of granular pyrolusite, either massive or with concentric structure. Crystalline pyrolusite and amorphous steel-blue psilomelane are associated with it but are much less abundant. Lenses of quartz, fragments of unaltered rock, and cavities lined with botryoidal surfaces likewise occur in the ore masses. The ore locally may compose 85 or 90 per cent of the ore-bearing layer, forming a nearly solid body with interstices filled with clay, while elsewhere more than half the layer may be clay in which the ore is embedded in lumps. The micaceous clay footwall is light brown, dark brown, or gray, by layers, and is residual from mica schist. The layers and schistosity have the same strike and dip. as the ore-bearing layer. The footwall clay is similar to the clay associated with the ore and grades imperceptibly into it. 


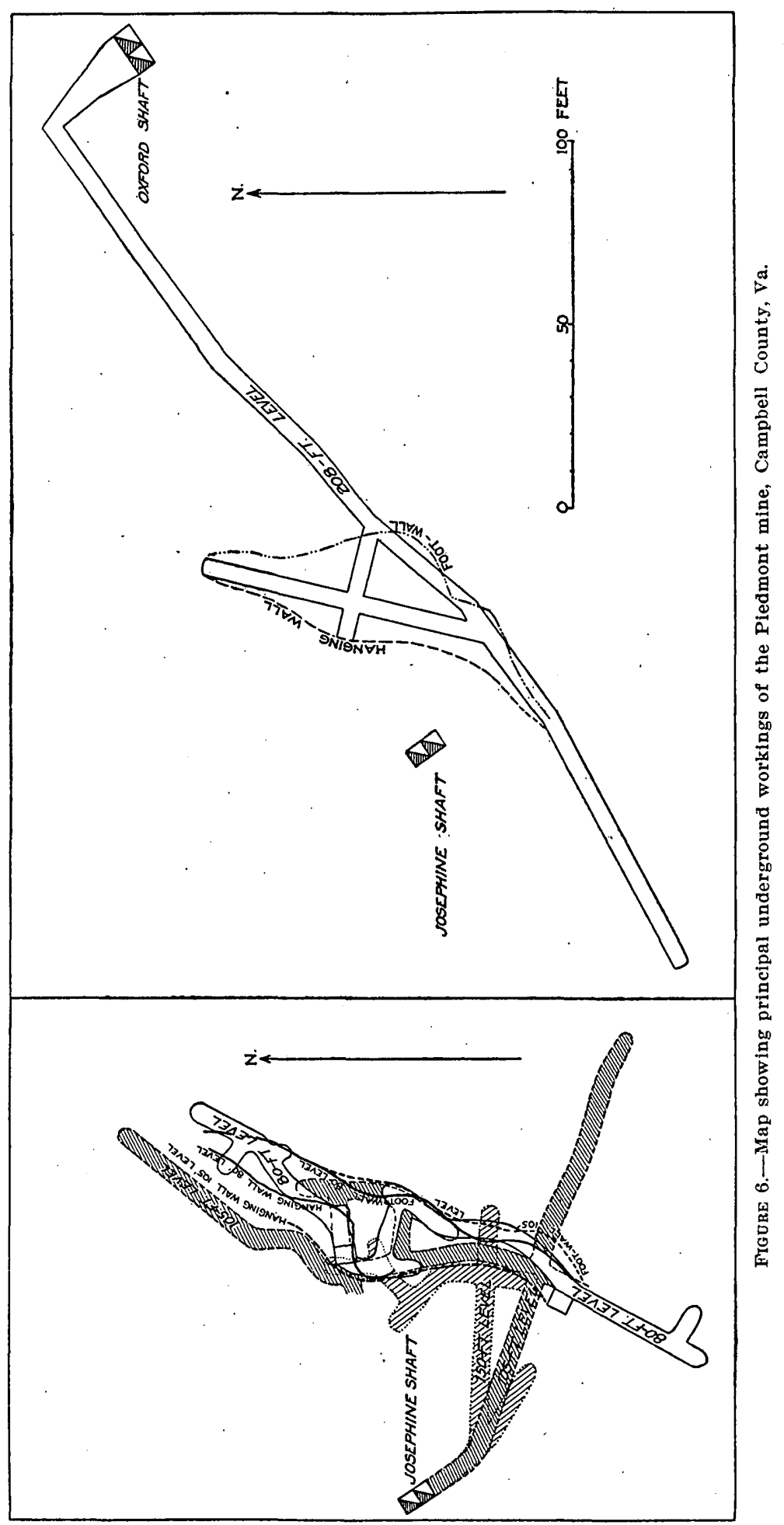


Further exploration has thrown some doubt on the determination by Harder that the hanging-wall rock is altered granite, for it merges with normal quartzite and quartz-mica schist. The footwall mica schist has been found to be only a few feet thick and separated from the thick lens of limestone by a thin layer of wad. An interesting and unusual feature of the hard ore is the presence in all specimens of plates of mica, which here and there give the ore a laminated appearance, but elsewhere are distorted and sporadic. By the examination of several thin sections cut at right angles to the lamination it has been observed that layers of perfectly preserved chlorite and muscovite pass from residual masses of quartz into the adjacent manganese minerals, which have clearly replaced quartz in part. The extent to which manganese minerals have formed in manganiferous clay resulting from the decomposition of silicate minerals is not clear, but it is certain that a considerable part of the ore has been formed by the direct replacement of the quartz of quartz-mica schist.

ORIGIN OF THE ORE.

The largest lens of manganese ore has clearly been formed by the replacement of quartz-mica schist, possibly locally calcareous, by manganese minerals. The manganese has probably not been derived from the adjacent wall rocks, for they are fresh, and qualitative tests on the micas fail to show the presence of appreciable manganese. As the deposit crops out near the crest of a knob that has been isolated since the beginning of the dissection of the early Tertiary peneplain, it has probably received very little manganese since the peneplain was dissected. The deposit presents the interesting feature of a narrow lens of highly oxidized minerals of superficial origin persisting to a depth of more than $\mathbf{1 7 0}$ feet below water level and 130 feet below the nearest large stream.

MILLING.

The crude ore is delivered from bins to a jaw crusher and then to a 22 -foot double $\log$ washer. The coarser material is sized in a trommel to three sizes, two of which are reated in four 3-compartment jigs, the coarse product being reground between rolls and added to the jig feed. In order to ship finely ground ore a 30 -foot dryer, a Hardinge mill, revolving screens, and a Huntington mill were recently added to the plant.

\section{MIDVALE MINE' ${ }^{1}$}

LOCATION AND HISTORY.

The Midvale mine is about 4,000 feet due east of Midvale, Rockbridge County, Va., on the Norfolk \& Western Railway. (See 
fig. 7.) The old mine workings are on the top of a broad spur that extends northwestward from South Mountain, a part of the Blue Ridge, at an altitude of 1,700 feet. A new tunnel extends northwestward under the old workings from a ravine 140 feet lower, and from the tunnel an aerial tramway extends to the mill near the railway, at an altitude of 1,120 feet. The mill contains a single log washer.

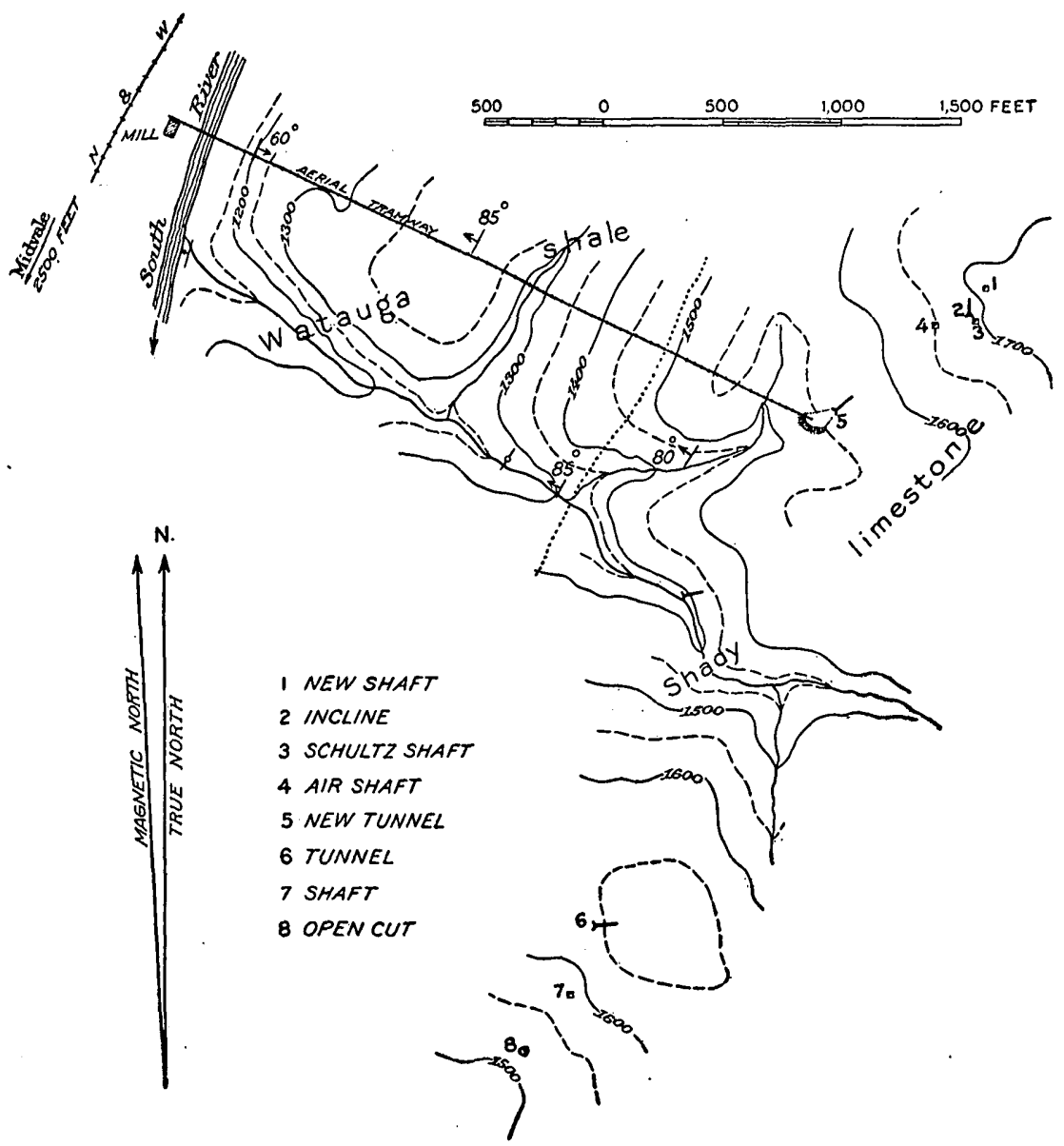

FIGUR 7.-Sketch map showing location of the workings of the Midvale mine, Rockbridge County, va.

The property was opened in the early eighties and was subsequently worked by Cohalan, Irwin \& Co., the Midvale Manganese Co., and Frank Schultz. The present lessee and operator is the Rockbridge Manganese \& Iron Co. The production from 1909 to 1914 , inclusive, was 914 tons, but there is no record of the earlier shipments other than 250 tons produced in 1887. 
SURFACE FEATURES AND GEOLOGY.

In the vicinity of Midvale, South River flows in a narrow, flat valley at an altitude of 1,100 feet. The ridges that abut against the valley on the southeast are spurs from the long, high ridge known as South Mountain and are characteristically flat-topped, attaining altitudes that range from 1,600 to 1,700 feet. Numerous remnants of a flat upland are also to be seen northwest of South River at similar altitudes. There is warrant for believing that these flat areas, which are cut in highly inclined rocks of diverse character, represent portions of the early Tertiary erosion surface.

The rocks that underlie the area near the mines are exposed along the ravine southwest of the mine and the clearing adjacent to the tramway. The following section was measured:

\section{Section near Midvale mine.}

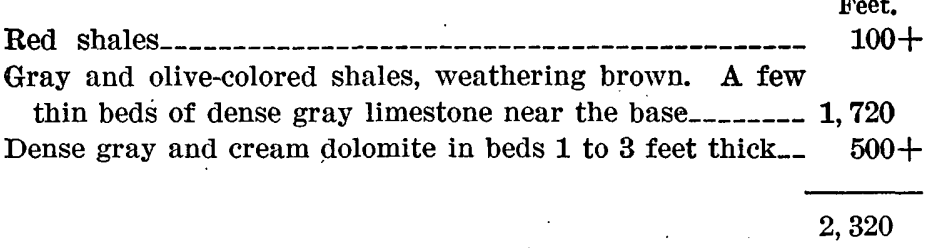

According to G. W. Stose ${ }^{1}$ and Arthur Keith, ${ }^{1}$ who have made reconnaissance examinations of this part of the Blue Ridge, the lowest unit is undoubtedly a part of the Shady or "Sherwood" 2 limestone (substantially the'same as the Tomstown limestone of Maryland and Pennsylvania), and the upper units are a part of the Watauga ("Buena Vista"2) shale (probably the same as the Waynesboro formation of Maryland and southern Pennsylvania), all of Cambrian age. Farther east, beyond the limits of the area shown in figure 7, the main ridge of South Mountain is composed of nearly vertical beds of Cambrian quartzite, but no rock outcrops were found between the mine and the ridge. The mine workings appear to be above the dolomite beds that are well exposed in the ravine 500 feet to the southeast, and there are dolomite outcrops northwest and above the mouth of the new tunnel. With the exception of the uppermost shale beds near South River, which are inclined southeast, all the outcropping lower beds dip from $80^{\circ}$ to $85^{\circ}$ NW. There is little doubt, therefore, that the normal succession of rocks is present in this belt and that there are no faults of great magnitude in the vicinity of the mine.

\footnotetext{
1 Personal communication.

2 Campbell, H. D., The Cambro-Ordovician limestones of the middle portion of the Valley of Virginia : Am. Jour. Sci., 4th ser., vol. 20, p. 445, 1905.
} 
OCCURRENCE OF THE ORE.

None of the explorations made prior to 1912, except the incline, are now accessible. The following explorations are reported: 'I'he Schultz shaft $(3$, fig. 7$)$ with drifts at several levels; the incline with connected drifts (2); and the new shaft (1) with levels at 50,70, and 105 feet, of which the 50-foot level was in 1914 extended through a connection with the incline, as shown in figure 8 . The accessible explorations include the new tunnel (5) with connected drifts and the

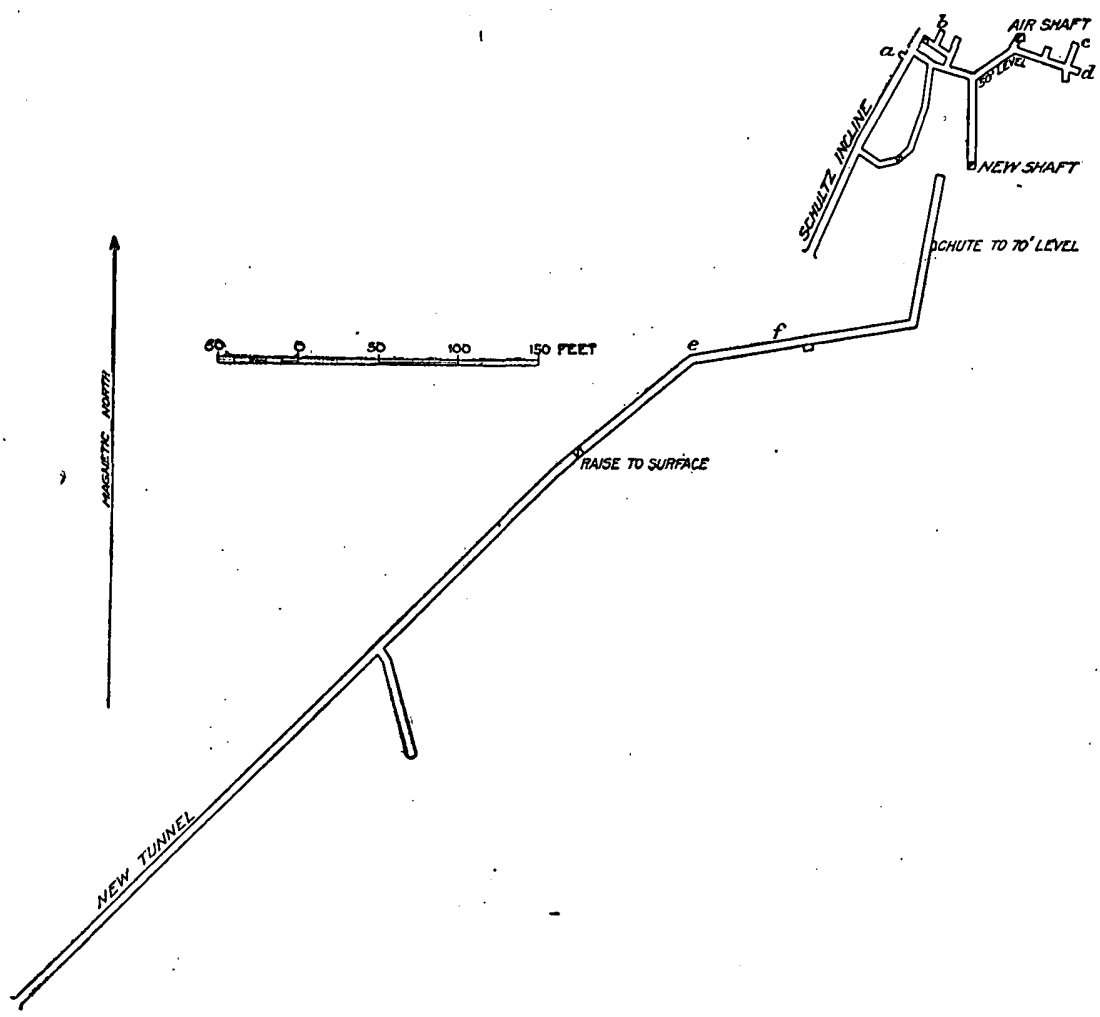

Figure 8.-Plan of the principal underground workings of the Midvale mine, Rockbridge County, va.

50-foot level. The production since 1909 has come from the Schultz shaft, incline, and new shaft.

The drifts on the 50 -foot level have struck manganese ore at a number of places, and most of the material mined during exploration has been washed. Although films of manganese oxide occur here and there on the tunnel level, no nodules of ore have yet been found. Typical modes of occurrences of ore are shown at $b$ and $c$, figure 8. As in residual deposits of manganese ore, the manganese minerals are embedded in clay, but the properties of the clay in this deposit are such as to warrant a different explanation of its origin. 
As seen in exposures on the 50-foot level the clay is generally sandy and contains here and there rounded pebbles of quartzite and quartz schist as large as 4 inches in diameter, as well as lenses of relatively clean reddish sand. Ordinarily the sand merges with the clay, but in a few places there is a sharp line of separation. Well-defined stratification is lacking. The clay is commonly mottled brown, but there are also patches of pure white, dark reddish brown, and pale rose-pink, the last a variety that resembles montmorillonite. The masses that are homogeneous in color are small. Pisolitic structure such as bauxitic clays commonly show is lacking, and although some varieties appear to contain considerable limonite, none harden on exposure, as most lateritic clays do.

In order to examine the properties of the coarse grains, several samples of sand and clay have been washed and screened with the results shown in the following table:

Screening tests of sand and clay from Midvale mine.

[Per cent.]

\begin{tabular}{|c|c|c|c|c|c|c|c|}
\hline Sample. & $\begin{array}{l}\text { On } 20 \text { - } \\
\text { mesh. }\end{array}$ & $\begin{array}{l}\text { On 40- } \\
\text { mesh. }\end{array}$ & $\begin{array}{l}\text { On } 60 \text { - } \\
\text { mesh. }\end{array}$ & $\begin{array}{l}\text { On } 80- \\
\text { mesh. }\end{array}$ & $\begin{array}{l}\text { On 100- } \\
\text { mesh. }\end{array}$ & $\begin{array}{l}\text { Through } \\
\text { 100-mesh. }\end{array}$ & $\begin{array}{c}\text { Clay in } \\
\text { suspension. }\end{array}$ \\
\hline 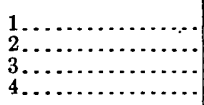 & $\begin{array}{r}0 \\
1.2 \\
3.0 \\
15.7\end{array}$ & $\begin{array}{l}0.6 \\
8.1 \\
7.3 \\
4.7\end{array}$ & $\begin{array}{r}1.8 \\
17.0 \\
9.4 \\
3.4\end{array}$ & $\begin{array}{l}0.6 \\
6.2 \\
4.2 \\
1.3\end{array}$ & $\begin{array}{l}0.6 \\
4.8 \\
3.3 \\
1.4\end{array}$ & $\begin{array}{r}2.8 \\
18.7 \\
17.0 \\
4.5\end{array}$ & $\begin{array}{l}93.0 \\
44.0 \\
55.8 \\
69.0\end{array}$ \\
\hline
\end{tabular}

1. Lens of mottled brown and red sandy clay from point marked $a$, figure 8 . The sands are largely flat angular grains of fine-grained quartz, with a few of psilomelane. Rounded grains are lacking.

2. Red sand from point marked $c$, figure 8. Most of the grains above 60-mesh are well-rounded quartz. There are a few coarse grains of quartzite. Relation of sizes is that of normal stream sand.

3. Light reddish-brown sandy clay from point marked $d$, figure 8. Very similar to No. 2 except that there are more coarse quartzite grains.

4. Dark-brown to black wad, with manganese nodules, adjacent to No. 3 at point marked $d$, figure 8 . There are only a few rounded quartz grains. Sand is largely psilomelane grains, one of which was 10.6 per cent of sample.

There can be little doubt that the sands from Nos. 2 and 3 are stream worn and not formed by residual decay or brecciation. Although most of the grains are single grains of quartz, many are, like the larger pebbles found in the clay, quartzite and quartz schist, closely resembling the Cambrian quartzite that underlies the Shady limestone. The grains of No. 1 are angular and the faces of some present a mammillary appearance. They are composed of microgranular quartz and appear to be fragments of minute veinlets of secondary origin.

The pebbles found on the 50-foot level range in size from coarse. sand to pebbles 4 inches in diameter and in shape range from subangular to well rounded. They do not occur in defined lenses but are scattered here and there in both the sand and the sandy clay. In many of them the cementing material is decomposed and the pebbles crumble under slight pressure. On the new tunnel level sand 
predominates over clay and there are more pebbles that tend to occur in lenses. Near the point marked $f$, figure 8 , on the level a rounded bowlder of quartzite 36 inches long was embedded in sandy clay and a few feet farther north decomposed siliceous dolomite was struck on the floor of the drift. A raise near the face of the tunnel has cut a zone of gravel-bearing sand. The relations of the materials on this level strongly suggest that the tunnel has been run close to the bottom and near the west edge of a filled river channel. Although the channel appears to trend northeast, the east limit and shape have not been determined.

The entire mass of clay and sand is wet, but there are few watercourses and little water flows from the mine workings. The clay is sufficiently plastic in places to flow slowly through small open spaces between the lagging in the drifts.

The hard manganese ore appears to be confined to highly irregular masses of dark-brown wad and manganiferous clay embedded in the variegated clay. No ore or wad has been found in the zones of sand. The masses of wad have a great range in size and shape and the limits of the larger bodies have not been determined. Some are rudely lenticular and are disposed in various positions. Locally the limits are sharply defined, but generally wad merges with reddishbrown clay.' It is possible that certain horizontal zones contain more manganese than others, but this has not been determined.

Psilomelane is the commonest manganese mineral in the washed product. It forms both rounded or botryoidal nodules and slaglike stalactitic masses. Some nodules show considerable manganite, much of which forms terminated crystals lining cavities. One polished section shows nuclear masses of fine crystals of manganite enveloped by numerous alternating fine bands of psilomelane and manganite. These two minerals appear to have been deposited alternately, but at one place in the specimen manganite may have been formed by the hydration of psilomelane. Limonite nodules have been found sporadically on the 50-foot level.

The following analysis was furnished by Mr. H. L. Whitney, manager of the mine:

Analysis of washed ore from Midvale mine.

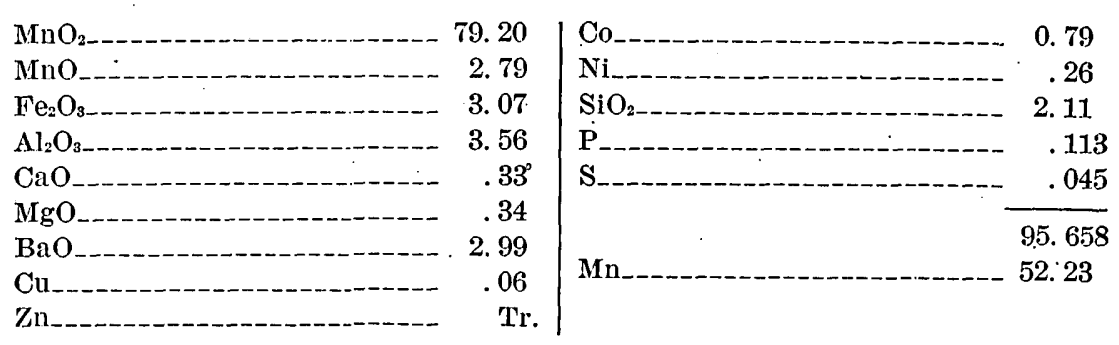


The yield of washed ore has not been accurately determined, except on a small scale on material from the manganiferous clay. Samples run from 25 to 50 per cent concentrate of all sizes down to fine sand. The ordinary log washer does not, however, recover lumps smaller than half an inch, so that under milling conditions the yield would probably be lower than this figure.

In addition to the deposit that has been the scene of recent operation, old explorations indicate the existence of a similar deposit on another spur from South Mountain, 3,000 feet to the southwest. Well-rounded quartzite pebbles were noted both in the clay exposed in the tunnel walls (No. 6, fig. 7) as well as on the dump. Ore was taken from these workings and hauled to South River valley for washing. According to aneroid-barometer measurements the lowest explorations in gravel-bearing clay on this hill coincide closely in altitude with the new tunnel on the northern deposit. No rock outcrops were observed near the southern deposit.

\section{ORIGIN OF THE ORE.}

The coarse gravel and bowlders, as well as the sand contained in the clay of the northern deposit, are such as are characteristic of river sediments rather than residual or fault-zone clays. The coarse sediments resemble the rock of which the high ridge 1,500 feet east of the deposit is composed but are entirely different from the rock that underlies it, as shown by exposures underground and in adjacent ravines. The angular grains of quartz washed from one specimen of clay are probably parts of veinlets deposited from the solutions with which the clay is saturated. It is suggested that these manganese deposits occur in remnants of channel sediments. laid down by a river that flowed on the surface of the early Tertiary peneplain. As the manganese nodules show no evidence of rounding by attrition or crushing, it seems probable that they have been formed in the manganiferous clay where they are now found. Although the. extent of the ore-bearing clay is not known, the amount of manganese in the channel filling is clearly greater than is present in ordinary sediment. Manganese has therefore probably been brought into the channel from outside sources by circulating solutions, but as both deposits occur on spurs which since the dissection of the Tertiary plain have received little surface drainage or underground water, it is clear that the deposition of the manganese must have taken place in early Tertiary time, before the plain was dissected.

If this explanation of the origin is correct, the manganese minerals will probably be found only in the river sediments. The underlying dolomite is much decomposed, but whether it originally contained sufficient manganese to yield workable deposits by weathering alone is doubtful. 


\section{IYNDHURST IMINE. ${ }^{1}$}

The Lyndhurst mine lies west of Buck Creek, 2 miles southeast of Lyndhurst station, Augusta County, Va., on the Norfolk \& Western Railway. According to Weeks ${ }^{2}$ the first opening was made in 1859. In $1885-86$ there was considerable development by the Virginia Manganese Mining Co., which obtained some ore from a shaft 65 feet deep. After another lapse the property was worked by Kendall $\&$ Flick for several years, until 1908, when it was finally abandoned. Although none of the underground workings were accessible in 1914, the deposit is mentioned here because the character of the material on the dump and the relation of the explored zone to the early Tertiary peneplain suggest a similarity to the conditions found in the Midvale deposits.

The collars of the old shafts are on a terrace 15 feet above the bed of Buck Creek and about 50 feet below the level of the early Tertiary peneplain, which in this vicinity has an altitude of 1,450 to 1,500 feet and is but slightly trenched by the present drainage. The material on the dump contains numerous well-rounded pebbles and bowlders of quartzite and chert, and in many of the lumps of psilomelane there is considerable well-rounded as well as angular sand and gravel. Although some ore occurred near the surface, a 20-foot zone was encountered at a depth of 65 feet that was richer in ore than the higher ground. ${ }^{3}$

There are no rock outcrops in the vicinity.

\section{KENDALI \& FIICK IMINE.4}

LOCATION AND HISTORY.

The Kendall \& Flick mine, also known as the Mary Campbell, comprises two groups of workings on the north slope of an isolated hill a mile south of Elkton, Rockingham County, Va. (See fig. 9.) The older workings, consisting of several open cuts, shafts, and tunnels that lie along a deep ravine tributary to Shenandoah River, were operated intermittently between 1888 and 1909, and a considerable tonnage of iron and manganese ores was shipped. The newer workings, 2,000 feet to the north, consist of several pits and a shaft with extensive underground drifts, which were opened in 1910 and operated almost continuously until January, 1915.

The material taken from the old workings was hauled in wagons to a mill on the Norfolk \& Western Railway, a mile to the north, to be washed. This mill burned in 1909, and in 1911 a modern mill was built on the same site.

\footnotetext{
1 Harder, E. C., op. cit., p. 62 . Fontaine, W. M., Notes on the mineral deposits at certain localities on the west part of the Blue Ridge : The Virginias, p. 55, 1883.

2 Weeks, J. D., U. S. Geol. Survey Mineral Resources, 1885, p. 317, 1886.

3 Idem, p. 315.

4 Harder, E. C., op. cit., p. 57.
} 


\section{SURFACE FEATURES AND GEOLOGY.}

In the vicinity of Elkton there are numerous flat spurs from the hills east and southeast of the town that attain an altitude of 1,000 feet, as well as extensive level areas farther west at the same altitude. These flat areas are considered to be remnants of the early Tertiary peneplain. Shenandoah River and its tributaries, such as Eik Run, flow in channels cut from 50 to 75 feet below this plain. The collar

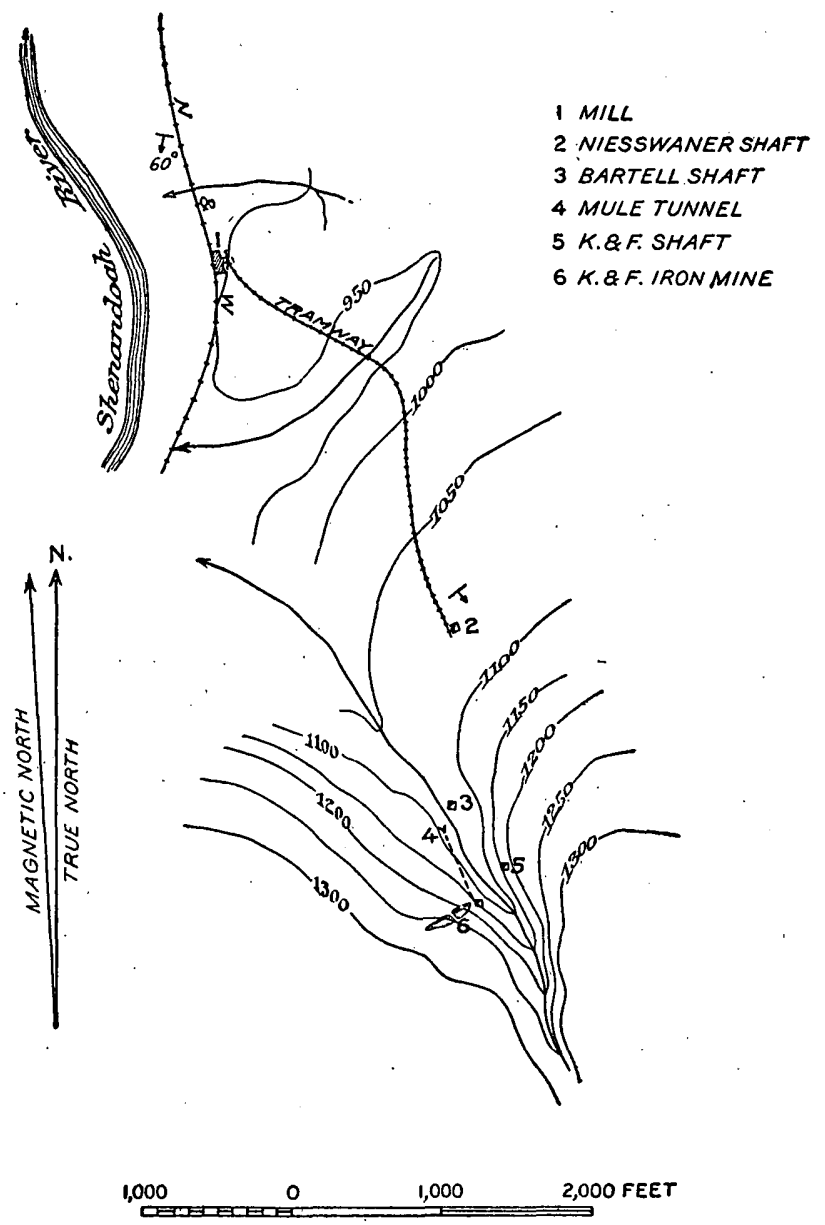

Frgure 9.-Sketch map showing location of the workings of the Kendall \& Flick mine, near Elkton, Rockingham County, Va.

of the Niesswaner shaft, at an altitude of 1,075 feet, or 153 feet above Shenandoah River, is on a gently sloping bench that merges with the plain to the north. The collar of the old Kendall \& Flick shaft is about 140 feet higher. Another shaft about 1,200 feet northeast of this shaft and about 50 feet higher is reported to have struck, at a depth of 110 feet, or about 1,165 feet above sea level, a lens of coarse, 
well-rounded quartzite bowlders apparently lying on shale and sandstone bedrock. The material is clearly waterworn, but it is not certain whether the bowlders lie on a terrace or in a channel.

No exposures of bedrock were noted in the area between the Kendall \& Flick open cut and the mill, but time did not permit an exhaustive search. Gray shale and thin-bedded limestone are exposed in the railroad cut 600 feet north of the mill. These beds are locally crumpled, but the strike is east and the dominant dip $60^{\circ} \mathrm{S}$. The Niesswaner shaft passed gradually from the clay in which manganese ore was found into soft, decomposed shale and finally, at a depth of 270 feet, into hard, mud-cracked red shale. The mud cracks show that the shale is not overturned. The face of the west drift on the 300 -foot level also shows similar shale with a strike of N. $30^{\circ} \mathrm{E}$. and dip of $10^{\circ} \mathrm{SE}$. Decomposed buff shale having a strike of N. $30^{\circ} \mathrm{E}$. and dip of $50^{\circ} \mathrm{E}$. was also seen in the face of the west drift of the 206-foot level.

The shales of the Niesswaner shaft are tentatively regarded as belonging to the upper part of the Watauga shale, but the correlation of the beds in the railroad cut is uncertain. The local physiog.raphy indicates that the structure on the west flank of the Blue Ridge may be complex, and considerable areal work may be necessary to determine the correlation and broader structure of the beds in which the deposits are found. The manganese deposit appears to be inclosed in a pocket of clay, resulting from the decomposition of the red shale in place.

\section{OCCURRENCE OF THE ORE.}

With the exception of the open cut (No. 6, fig. 9), none of the openings made by Kendall \& Flick were accessible in 1913. The main shaft (No. 5) is reported to have been 256 feet deep when work was abandoned in 1909 , but there is no record of the occurrence of the ore. Iron ore only was taken from the open cuts, but it is reported that some manganiferous ore was obtained from the deep workings and removed through the mule tunnel (No. 4). The walls of the eastern open cut show decomposed sandy shale, here and there impregnated with limonite and containing thin films of manganese oxide. During 1915 a new shaft (No. 3) was sunk to a depth of 135 feet in the ravine, but encountered only valley wash containing subangular bowlders of quartzite.

It is reported that the amount of ore mined above the 140-foot level of the Niesswaner shaft was not great, but the upper work was not accessible in 1913. This shaft reached a depth of 312 feet in May, 1914, but no ore was found below 260 feet, or 105 feet below the level of the Shenandoah River, 3,000 feet distant, and 220 feet below 
the original water level. Most of the crude ore that yielded the output from 1912 to 1914 came from the ground between the 140-foot and 206-foot levels. As shown by the sections of figure 10, the zone which yielded the ore, and was therefore most thoroughly explored, was roughly $U$-shaped in cross section and about 30 feet in maximum thickness on the arms. The explorations do not appear to have determined the horizontal limits of the ore-bearing zone, except at the face of the southwest heading, where decomposed shale was found. Within this zone hard rounded and slaglike masses of manganese minerals were found, for the most part in dark-brown to black wad, which formed highly irregular bodies in soft variegated clay. Locally, hotvever, the manganese minerals were embedded in pure ocher containing little manganese, but none were observed in white or pale-yellow clay. Although some bodies of wad were small and apparently isolated, many of the larger bodies were connected by irregular pipes and seams of wad, and by following these it was possible to locate new bodies in the zone. As the explorations and stoping tended to follow the ore, the result in places was a veritable maze of drifts and raises.

Although the round ore nodules are generally solid, many of the slaglike masses are cavernous and stalactites of psilomelane hang vertically from their walls. Psilomelane appears to be the commonest mineral, but many nodules show manganite and psilomelane in alternate bands, and in several places manganite crystals fill fractures in psilomelane. It is reported that in systematic sampling the crude ore yielded washed ore in the ratios of 3 to 2 and 3 to 1 ; but from the mill records it is doubtful whether a ratio of 3 of crude to 1 of washed ore was maintained over long periods. A few masses of ore weighing as much as 500 pounds have been found, but most of the nodules range from 1 inch to 4 inches in diameter. In addition to ore the washed product contains subangular fragments of microcrystalline quartz that resemble chert and range in size from fine sand to pieces 2 inches in diameter. Fragments of sedimentary rocks have never been found in the mass.

The clay adjacent to the ore bodies is commonly yellowish brown, but here and there variegated, white, gray, and dark brown. It merges both laterally and below into a zone of pale-brown decomposed shale, in which traces of bedding may be recognized. No hard nodules of manganese occur in this shale, although there are films of manganese oxide here and there along bedding planes. The thickness of this zone appears to range from a minimum of about 20 feet under the deposit in the shaft to more than 90 feet on the 206-foot level.

Although the important crystalline constituents of the clay have been recognized under the microscope, the exact nature of the changes 


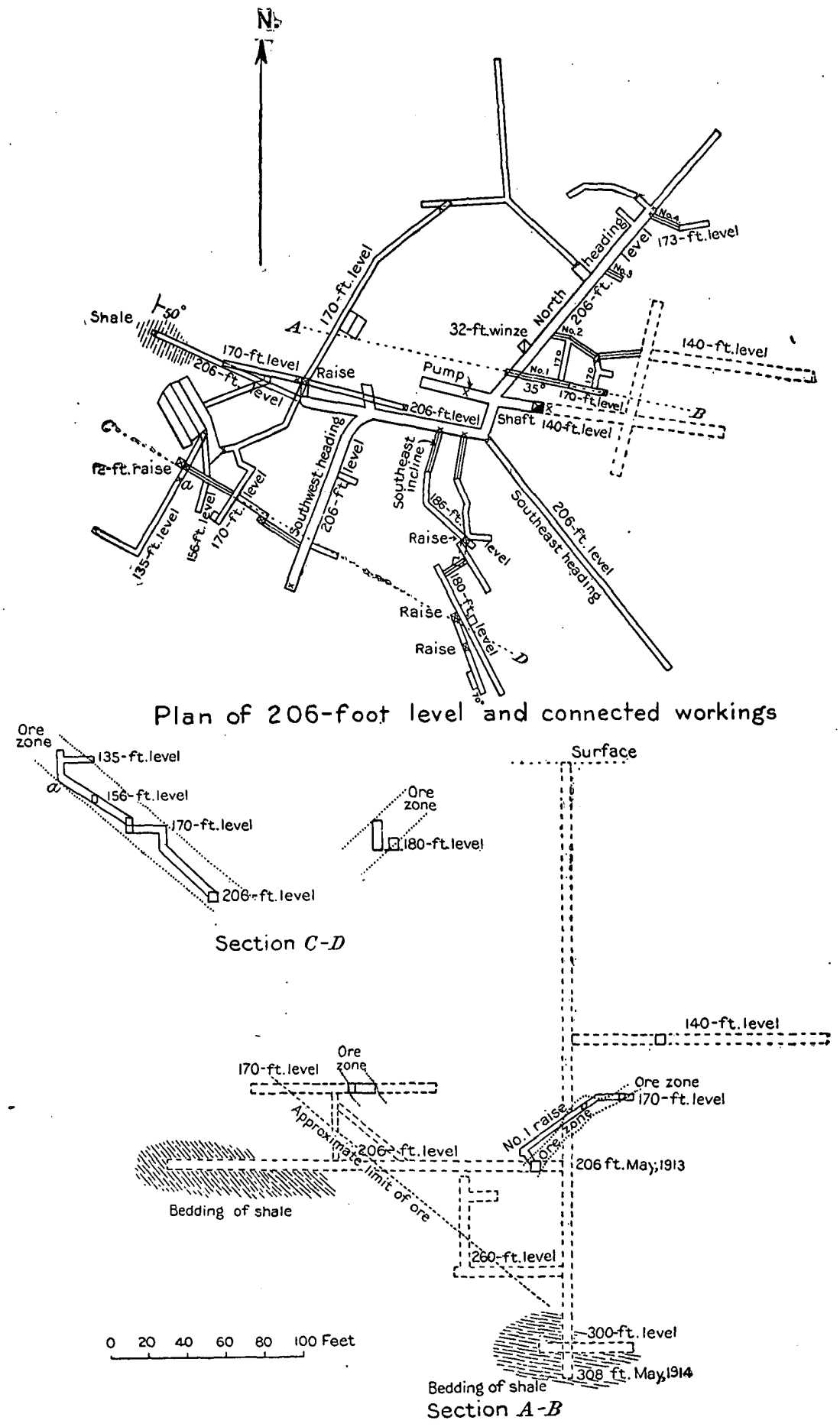

Frgure 10.-Flan and cross sections of the Niesswaner shaft, Kendall \& Flick mine, near Elkton, Rockingham County. Va. $X$, limit of accessibility in underground workings. 
undergone by the shale in decomposing to clay can not be determined, because the colloidal materials that make up the bulk of the clay appear similar and may, nevertheless, show a wide range in composition. The unaltered coherent shale contains considerable sericite, ferric oxide, clay, quartz, and possibly minor accessory minerals. The soft shale at the face of the west drift on the 206foot level also contains sericite, clay, and quartz, but, except for the change to a soft yielding mass, does not appear to differ greatly from the unaltered shale. Some of the clay near wad and nodules of manganese minerals is gray or white and contains considerable sericite and quartz, but most of it is yellowish-brown clay substance with very little sericite and quartz. Some specimens contain angular platy fragments of microgranular quartz and others, such as that collected at the point marked $a$, figure 10, contain numerous minute quartz crystals, with many calcite nuclei. Both these forms of quartz appear to be secondary in the clay and to be formed as a result of the decomposition of the shale.

The comparison of the partly altered shale and clay appears to indicate that much of the clay substance has been formed by the decomposition of sericite. If the clay approaches in composition that of kaolin, in which the ratio of silica to alumina is the same as in sericite, silica is not necessarily set free. It is possible, however, that the decomposition of sericite might yield potassium carbonate, which is capable of dissolving quartz at one place and depositing it at another. The alteration of sericite to kaolin may take place with little change in volume, and it is therefore possible that the clay in which the manganese occurs and is commonly called residual clay may represent essentially an equivalent volume of shale.

The purpose of the study set forth above was to ascertain whether it is more probable that the masses of manganese ore, which obviously represent more than that contained in a volume of fresh shale equal to that of the clay, represent an enrichment of manganese through loss of shale constituents by solution or whether the volume of the clay has remained essentially constant and manganese has been added. If the clay has approximately the composition of kaolin, the latter assumption appears more reasonable.

ORIGIN OF THE ORE.

The relations of the hard manganese minerals to wad and clay suggest the following mode of origin: The clay in which the manganese is found was in part a constituent of the original shale and in part has resulted from the decomposition of sericite. Hydrous oxide of manganese, partly an original constituent in the shale but largely brought into the clay mass in solution, first replaced the clay by forming segregated masses of soft wad. Locally masses of fairly pure 
but incoherent hydrous manganese oxide were formed. The nodules of ore have formed in wad, largely by the deposition of successive bands of psilomelane and manganite, but partly by the replacement of clay.

MILLING.

In the new mill erected in 1911-12 the mine dirt is elevated to bins, from which it is fed to a trommel with $1 \frac{1}{2}$-inch holes. The oversize, consisting of nodules of ore and masses of mud, is crushed in rolls and joins the screened product, and both pass through a double log washer. The washed ore is sized in a double trommel to three products, the coarsest of which, above $1 \frac{1}{2}$ inches, is hand sorted, while the middling, ranging from $1 \frac{1}{2}$ inches to one-fourth inch, is sized and jigged in a McLanahan jig. An attempt was made to treat the finest material on a Wilfley table, but it was abandoned, as a high-grade product could not be made.

\section{HAPPY CREEK MINE. ${ }^{1}$}

LOCATION AND HISTORY.

The Happy Creek manganese mine, operated by the Seibel Iron Mines (Inc.), lies on the north end of a low knob 3 miles east of Front Royal, Warren County, Va. The iron mine that was operated for a number of years by the same owners is 1 mile farther south, at the south end of the knob. Although the occurrence of manganese here has been known for a number of years, most of the present workings, consisting of two open cuts and several shallow shafts and pits, have been made since 1907. During 1914 manganese ore was mined by a steam shovel from a 45 -foot face of the northern open cut, and carried by narrow-gage tramway to the mill near Happy Creek, on the Southern Railway, 2,000 feet distant.

\section{SURFACE FEATURES AND GEOLOGY.}

Both mines are situated approximately at the line where the knob merges with the dissected upland, at an altitude of 800 feet. The channel of Shenandoah River, 2 miles to the north, is cut 350 feet below this upland, which is well developed along the valley both northeast and southwest of Front Royal.

Rock outcrops are poor in the vicinity of both mines, except along the knob and in the face of the largest iron-ore quarry. Here flatlying beds of quartzite containing interbedded lenses of quartz abut against a mass of angular quartzite débris and clay that appears 
to be fault breccia. The sandstone is regarded as the Antietam sandstone of Lower Cambrian age, and probably makes up most of the knob. West of the manganese mine there are outcrops of dense gray limestone and reddish shales, with northeast strike and varying southeast dip, which undoubtedly correspond to higher formations than the Antietam sandstone. The relations of these beds indicate the presence of a thrust fault along the northwest edge of the knob, but its exact position has not been determined. This inference is strengthened by the geology of the west flank of the Blue Ridge in the Harpers Ferry quadrangle, ${ }^{1}$ the southwest corner of which lies 8 miles northeast of Happy Creek. In this region there are two thrust faults, the western of which if projected would pass east of Happy Creek near the manganese mine.

\section{OCCURRENCE OF THE ORE.}

The best exposures of ore are shown in the face of the northeast open cut, which is about 300 feet long and covers slightly more than an acre. Little ore is exposed in the other open cut, which lies about 250 feet to the southwest and covers about a quarter of an acre. At the first location hard slaglike masses of manganese minerals are sporadically distributed in yellowish-brown clay in two nearly' vertical lenticular zones which range from 5 to 8 feet in width and trend south. There is little difference between the color of the clay in which the manganese minerals occur and that of the clay immediately adjacent, although elsewhere the manganese-free clay is mottled reddish brown, light brown, and white.

The hard manganese minerals here do not appear to be confined to masses of wad and manganiferous clay, as they are in some other deposits on the west slope of the Blue Ridge. Small irregular patches of wad occur here and there in relations which show clearly that the wad replaces clay, but it forms a small part of the mass. The nodules range in size from very small grains to some 8 inches in diameter. Many show an inner zone of concentric bands of radiating crystals of manganite enveloped in botryoidal psilomelane. Limonite nodules are also present, and to get a good grade of manganese ore for shipping these must be eliminated by sorting. In mining only the richest zones are selected, and ordinarily two carloads or about 8 cubic yards of mine dirt yield 1 ton of ore. When the proportion of limonite becomes too great to be profitably eliminated by sorting, a mixed iron and manganese product is shipped. The ratio of washed to crude ore may then rise to 1 ton to 3 cubic yards.

Along a part of the west face of the large open cut a poorly defined bed of bowlders, coarse gravel, sand, and clay about 15 feet

${ }^{1}$ Kelth, Arthur, U. S. Geol. Survey Geol. Atlas, Harpers Ferry follo (No. 10), 1894. 
thick is exposed, and although it contains some wad, it appears to overlie the mass of manganese-bearing clay. The gravel contains well-rounded pebbles of chert, quartzite, and sandstone, the largest 18 inches in diameter.

The underlying clay adjacent to the manganese zones yields, after the flocculent part is washed away, about 5 per cent of residue that is principally angular quartz sand, with a few grains of psilomelane and many minute quartz crystals containing nuclear grains of calcite and clay substance, such as occur in the clay near ore in the Niesswaner shaft, near Elkton. The surfaces of the quartz crystals are pitted, but there is no evidence of abrasion and they appear to have formed in the clay. The flocculent part contains traces of sericite. This clay is not so clearly stream-channel material; but resembles the residual clay of the Elkton deposit.

ORIGIN OF THE ORE.

Only a superficial zone of this deposit has been explored, and, as in many other places, this zone contains considerable limonite together with manganese oxides. Although a fault plane probably lies within a short distance of the deposit, it is not certain that the ore is confined to the fault. The clay with which it is associated may be derived in part from shale of one of the Cambrian formations. The presence of the ore under stream gravel lying on the early Tertiary peneplain appears to be significant.

\section{MILLING.}

At the mill crude ore is dumped into the lower end of a double log washer, from which the clean coarse material is delivered by a belt to a trommel. This delivers sizes of 1 and 2 inches and an oversize which is crushed in a jaw crusher, elevated, and separated into two sizes in a second trommel. All material between 1 and 2 inches is treated in a one-compartment coarse jig, which produces shipping ore and a product that is crushed in Cornish rolls and returned to the second trommel. A two-compartment jig treats the material between half an inch and 1 inch and yields shipping ore and tailing. A three-compartment jig treats the fine material and delivers shipping ore and tailing. This plant has produced 300 tons of washed ore a month.

\section{DARGAN MINE.}

LOCATION AND HISTORY.

The Dargan mine is on the north side of Potomac River about a mile southwest. of Dargan, a settlement in Washington County, Md. 
(See fig. 4, p. 38.) It is reported that it was opened by a shaft near the Chesapeake \& Ohio Canal in the early seventies, but the most serious attempt to exploit the deposit extended over the period 1908 to 1910 , when a new shaft was sunk in an open cut to a depth of 50 feet and drifts were run 190 feet to the north. As the result of sporadic explorations in a 50-foot vertical zone 60 tons of goodgrade lump ore and 90 tons of low-grade washed ore were mined.

\section{SURFACE FEATURES AND GEOLOGY.}

Although this deposit has produced little ore, a description of it is warranted because the structural relations are so clearly shown in the natural exposures and mine workings, and because it appears to have unique physiographic relations. The mine workings lie at the south end of a narrow ridge that rises 720 feet above sea level, or about 70 feet above the level of the upland that represents the early Tertiary peneplain. The collar of the shaft is 290 feet above sea level, or 25 feet above the normal stage of the river, and at a point 100 feet north of the river manganese ore has been mined 25 feet below water level, or about 410 feet below. the level of the early Tertiary plain.

There are numerous exposures of gray and brown micaceous sandstone along the crest of the ridge and of hard gray micaceous shale - lower down, which are referred by Keith ${ }^{1}$ to the Antietam sandstone and Harpers shale, respectively. Both are inclined steeply to the east. As shown by exposures west of the mine workings, the beds of shale abut against the beds of limestone that form the east limb of a low anticline. This limestone is referred by Matthews and Grasty ${ }^{2}$ to the Tomstown limestone, which normally overlies the Antietam sandstone and Harpers shale. There is little doubt that the contact between the Harpers shale and the limestone, as shown by Keith, is a thrust fault of considerable magnitude. Explorations for manganese ore are confined to the zone of decomposed rock that lies along this fault.

OCCURRENCE OF THE ORE.

The shaft and connected drifts were not accessible at the time of examination (May, 1912), but several faces of drifts from the open cut showed manganese minerals. These form hard slaglike nodules of roughly spherical shape, with a maximum diameter of 20 inches. Most of these nodules are made up of alternating concentric layers of psilomelane and manganite, which separate when struck with a

${ }^{1}$ Keith, Arthur,.U. S. Geōl. Survey Geol, Atlas, Harpers Ferry folio (No. 10), 1894.

2 Matthews, E. B., and Grasty, J. S., The limestones of Maryland : Maryland Geol. Survey, vol. 8, pt. 3, p. 401, 1909. 
hammer. No brown manganiferous wad was found, but there are irregular patches of soft pyrolusite that replaces clay. The clay in which the nodules occur is variegated light yellowish brown to brown and contains numerous impressions of angular shale fragments which show that it is largely a decomposed fault breccia. Although the color of the clay is clearly due to hydrated iron oxide, no nodules of this mineral have been encountered.

According to the available data explorations were confined to a zone adjacent to the limestone on the west, not more than 50 feet wide, although in an incline from the south into the old workings the shale is decomposed over a greater width. It is reported that the fresh limestone presented a very irregular rounded surface toward the fault-breccia clay, a feature that suggests corrosion of the limestone by circulating solutions.

The fault zone has been explored by a tunnel on the west side of the ridge at a point 4,000 feet north of the old workings near the canal, and although only a few manganese nodules were found, the fault breccia has the same characteristics.

No record of the amount of washed ore yielded by a definite quantity of crude ore has been kept, but the proportion appears to have been rather low.

ORIGIN OF THE ORE.

If, as appears to be the case with the other deposits, the Dargan deposit was largely formed during the early Tertiary period of erosion, ore must have extended about 410 feet below the adjacent surface at that time, or 150 feet lower than the limit of ore at Elkton. The amount of ore mined in the deepest zone of the Dargan deposit is small compared to that taken from the other deposits, and it may be that the lower limit of ore was reached. The ease with which the fault zone permitted the circulation of ground water, however, may account for the greater depth to which ore was deposited. 
